\title{
Determinant Factor Analysis of Traveler Loyalty by Push and Pull Motivation
}

\author{
Rivaldi Arissaputra', Sarah Sentika ${ }^{2}$ \\ ${ }^{1,2}$ Department of International Trade, 'Aisyiyah University Bandung, Indonesia \\ rivaldi.arissaputra@unisa-bandung.ac.id,sarahsentika@unisa-bandung.ac.id
}

\begin{abstract}
As a network of creative cities by the United Nations Educational, Scientific and Cultural Organization (UNESCO), Bandung announced that the city of Bandung was listed as one of the innovative city networks of the UNESCO Creative Cities Network, which is very attractive for tourists. In general, tourists are divided into different segments. Geographical segmentation in terms of area is the most prominent thing among tourists, especially in this study. The research subjects were tourists from the Greater Jakarta area who had visited Bandung several times. The sample used in this study was 100 people, conducted using a questionnaire and processed by descriptive-verificative analysis techniques. This study aims to explain the determinants of tourist loyalty to the city of Bandung by measuring the influence of the driving motivation and pull motivation variables on tourist loyalty. The results showed that the driving motivation did not affect the loyalty of Jabodetabek tourists, while the pull motivation affected the loyalty of Jabodetabek tourists.
\end{abstract}

\section{Keywords}

Loyalty; push motivation; pull motivation; tourism



\section{Introduction}

The tourism industry is a collection of business fields that produce various goods and services needed by people who travel for tourism. According to UNWTO ( United Nations World Tourism Organization ) in The International Recommendations for Tourism Statistics 2008, the tourism industry includes; food and beverage service activities, passenger transportation, accommodation for visitors, travel agents, cultural activities, sports and entertainment activities. Tourism Law No. 10 of 2009 states that the Tourism Industry is a combination of interrelated tourism businesses to produce goods or services to meet the needs of tourists in the implementation of tourism.

Tourism is the most important economic factor in Indonesia. This is evidenced by the fact that tourism ranks third in foreign exchange earnings after oil and gas commodities and palm oil in 2009. Tourism itself is one of the sectors driving the country's economic growth. With the potential for natural and cultural tourism that is so large, Indonesian tourism is one of the biggest foreign exchange earners for the Indonesian economy. The total number of foreign tourists who came to Indonesia in 2014 was more than 9.4 million, or $7.05 \%$ compared to 2013. This shows that tourism is a prospective sector with a relatively significant increase in investment realization. This increase is also supported by the government's plan to revise Presidential Regulation 39 of 2014 regarding closed business fields and business fields open to investment.

Bandung is one of the most popular cities for tourist destinations. Bandung City is the provincial capital and metropolitan city of West Java Province. Bandung has made several essential histories, including the establishment of the first technical college in Indonesia, Technische Hogeschool te Bandoeng and now changed to the Bandung Institute 
of Technology (ITB); the location of the battle arena during the independence period as well as the venue for the Asian-Asian Conference Africa 1955. Based on a Times magazine Survey in 1990, Bandung was chosen as one of the safest cities in the world. Bandung is nicknamed the city of flowers because Bandung was considered very beautiful with the many trees and flowers that grew there in ancient times. In addition, Bandung was formerly also known as Paris van Java because of its beauty, known as a shopping city with many malls and factory outlets, and now Bandung is gradually becoming a culinary tourism city. In 2007, a consortium of several international NGOs made Bandung a pilot project for the most creative city in East Asia. Several nicknames and facilities obtained by Bandung make this city one of the main destinations for tourism and education.

The attractiveness of Bandung city as a tourist destination is getting higher with the recognition of Bandung as a creative city network by the United Nations Educational, Scientific, and Cultural Organization (UNESCO). That's announced that the city of Bandung was listed as one of the creative city networks of the UNESCO Creative Cities Network. This was conveyed by the Director-General of UNESCO, Irina Bokova, in 2015. According to this organization, seven categories can be used as role models for other cities, namely Crafts and Folk Arts, Design, Film, Gastronomy, Literature, Media and Musical Arts. Of course, these things will be a kind of tourist destination category in the city of Bandung. The visitors to this tourist destination are called tourists. As Bandung is one of the popular tourist destinations, tourists visiting the city of Bandung always increase from year to year. The following is data on tourists visiting the city of Bandung from 2011 to 2015.

Of course, in practice, every tourist has their reasons in deciding to visit the city of Bandung. The reason in question refers to the motivation felt by tourists. This motivation is thought to make tourists keep coming and coming back to visit the city of Bandung. Seeing from the side of the tourists themselves, of course, the classification of tourists, in general, is comprehensive with various backgrounds. Category of tourists from geographic segmentation, for example. Geographical segmentation in terms of area is the most prominent thing among tourists. According to (Kotler, 2000), market segmentation consists of a group of customers who have a set of similar needs and wants. According to (Kasali, 1998), segmentation is the process of dividing the (heterogeneous) market into groups of " potential customers " who have the exact needs or similar characters who have the same response in spending their money. Due to its homogeneous nature, it will be difficult for producers to serve it, therefore marketers must choose only specific segments and leave other parts of the market. The selected component must also be adjusted to the manufacturer's capabilities, and the selected part is a homogeneous part with the same characteristics. Neil (1997), quoted in (Kasali, 1998), explains that market segmentation must be carried out from the beginning, namely when the first process begins, analyzing market opportunities.

The purpose of this study will be to examine the determinant factors that shape tourist loyalty from the Greater Jakarta area and to know the effect of push motivation and pull motivation on the loyalty of Jabodetabek tourists. The reason different tourists return to Bandung impacts the formation of the determinants of allegiance. In this case, the motivation in question is the driving motivation, and the pulling motivation of a person is visiting a place.

The Big Indonesian Dictionary defines motivation (psychological) as an effort that can cause a particular person or group of people to be moved to do something because they want to achieve the goals they want. According to (Dharmesta \& Handoko, 1997), motivation is a natural state that encourages the individual's desire to carry out certain 
activities to achieve a goal. The motivation in a person will realize a behavior directed at the goal of achieving the target of satisfaction. So, motivation is not something that can be observed but can be inferred because of something that we can see. Every activity carried out by a person is driven by force from within that person; This driving force is called motivation. Therefore, we can know that consumer behavior starts with motivation. Definitively it can be said that consumer motivation is an encouragement of individual needs and desires directed at obtaining satisfaction.

The theory of motivation used in this research is the theory of push motivation and pull motivation. According to (Crompton, 1979), The driving motivation dimensions are (1) Escape from a perceived mundane environment, (2) Exploration and evaluation of self, (3) Relaxation, (4) Prestige, (5) Enhancement of kinship relationship, (6) Facilitation of social interaction and dimensions of puller motivation are (1) Novelty, (2) Education. (Awaritefe, 2004) adds that pull motivation has dimensions of (1) x Static Factor, (2)
Dynamic Factor
(3) Current Decision,
(4)
Commercial, and Information/Advertisement Destination.

According to (Kotler \& Keller, 2011), Customer loyalty is a deeply held commitment to rebuy or patronize a preferred product or service consistently in the future, despite the situational influence and marketing efforts having the potential to cause switching behavior. (Deeply commitment to repurchase or subscribe to the preferred product or service consistently in the future, situational influences and marketing incentives can cause behavior change). According to (Griffin \& Herres, 2002), the definition of loyalty is buying behavior, which is defined as a non-random purchase that is expressed from time to time by several decision-making units. Meanwhile, according to (Wirtz \& Lovelock, 2022), loyalty is the willingness of customers to continue to support a company in the long term, buy and use its products and services based on exclusive liking and voluntarily recommend the company's products to their relatives. In the first millennium, future orientation has shifted from a conventional approach to a contemporary one Bhote, 1996 cited by (Tjiptono, 2000). The traditional course emphasizes customer satisfaction, cost reduction of market share, and market research, while the contemporary practice focuses on customer loyalty.

Loyal customers are an invaluable asset for the company, which can be seen from its characteristics. As stated by Griffin quoted by (Hurriyati, 2005), loyal customers have characteristics that are also used as indicators in this study, including: 1) Making repeat purchases; 2) Buying outside the product line services (purchase across product and service line); 3) Recommend to others (referring other); 4) Demonstrate immunity from the attractiveness of similar products from competitors (demonstrates an immunity to the full of competition).

\section{Research Method}

This research is descriptive and verification because this research examines and analyzes a problem or phenomenon, explains the influence between variables, tests hypotheses, and obtains the implications or meaning of the issues to be studied. This research is also verified, where the purpose of this study is to examine the truth of the hypothesis through data collection carried out in the field to explain the influence of the variables perception, motivation, and career choice. Descriptive surveys and explanatory surveys are the methods used in this research. This method is used because it is used to describe the relationship between variables by testing the pre-determined hypothesis 
between the independent variables, namely pull motivation and push motivation and the dependent variable is tourist loyalty.

The required data will be classified into two groups in this study, namely primary and secondary data. Primary data is data obtained from distributing questionnaires to respondents who become tourists who are considered to represent the research population. In contrast, secondary data is data obtained from tourist activities, which comes from literature, articles, magazines, and scientific writings considered relevant to the research topic.

In obtaining sample data for primary data collection, the sampling technique used is Simple Random Sampling. Samples were taken from Jabodetabek tourists visiting the city of Bandung. To determine the sample of respondents can use the Slovin formula (Jalaluddin, 2004), as follows:

$$
\mathrm{n}=\mathrm{N} /\left(\left(\mathrm{Nd}^{\wedge} 2\right)+1\right)
$$

Note: $\mathrm{n} \quad=$ minimum sample size

$\mathrm{N}=$ population size

$\mathrm{d}^{\wedge} 2=$ level of precision

The number of tourists visiting the city of Bandung based on data from the Tourism Office in January - June 2016 was 6 million visitors. The error rate determined was $10 \%$ $(\mathrm{d}=0.10)$ the number of research samples $(\mathrm{n})$ was $\mathrm{n}=6,000,000 /\left(\left(6,000,000 \times(0,1)^{\wedge} 2\right)+\right.$ 1) $=99.99$ rounded up to 100 people. So, in this study, the total sample of respondents taken was 100 tourists from Jabodetabek.

The existing hypothesis "will be tested and proven true, is" as follows:

\section{Hypothesis 1}

HO : The driving motivation has no effect on the loyalty of Jabodetabek tourists

H1 : The driving motivation affects the loyalty of Jabodetabek tourists.

\section{Hypothesis 2}

H0 : Towing motivation does not affect the loyalty of Jabodetabek tourists.

$\mathrm{H} 2$ : Motivation affects the loyalty of Jabodetabek tourists.

\section{Hypothesis 3}

$\mathrm{HO}$ : There is no determinant factor that becomes a priority in motivating Jabodetabek tourists.

H3 : There are determinant factors that become a priority in motivating Jabodetabek tourists. 
The data collection techniques used in this study are divided into two, including (1) library research, which collects data studying written materials related to the research topic, for example, through books, journals, previous research, and literature. Relating to motivation, loyalty, and data on visitors to the city of Bandung from the Jabodetabek area to increase the author's knowledge and references to conduct a more in-depth discussion. (2) Field study (field research) is research conducted at the research site to obtain data directly through questionnaires. In this study, questionnaires were distributed to the respondents directly and via a google form. The measurement scale on the questionnaire uses a Likert scale, where the Likert scale serves to measure attitudes, opinions, and perceptions of a person or group of people about social phenomena. A measuring instrument is needed to measure a variable, which is usually called an instrument. In this study, the variables to be measured are broken down into indicators where the indicators become benchmarks for compiling instruments in the form of statements. The Likert scale statement were given a score of $4=$ strongly agree, $3=$ agree, $2=$ disagree, $1=$ strongly disagree.

Data processing techniques in this study consisted of descriptive analysis and verification. Descriptive analysis design is used to describe the characteristics of respondents and respondents' responses to the research variables that have been collected. The reactions from respondents are used to complete the discussion, and the answers are grouped into specific criteria to make it easier to interpret the variables studied.

Descriptive analysis is done by grouping the score of respondents' responses through the minimum and maximum score range by dividing the number of desired categories. Respondents' reactions to each statement item were categorized into 4 categories, namely very low, low, high, and very high with the following calculations: (1) Determining the range of the lowest and highest scores, by multiplying the number of samples studied, namely 100 with the highest, weight low on the Likert scale 1 and the highest weight 4 . Thus, it can be seen that the lowest range is $100 \times 1=100$ and the highest range is $100 \times 4=$ 400. (2) The percentage of the interval range for each criterion for a score, based on the minimum score and the maximum score, then the maximum value of the proportion score is:

(lowest score range/highest score range) x $100 \%$

$(100 / 400) \times 100 \%=25 \%$

From the maximum and minimum proportion scores, it is obtained that the proportion score range is $100 \%-25 \%=75 \%$, so for the interval value the proportion is $75 \%$ $14=18.75 \%$. (3) Determine the range of score classifications per statement item and give categories very low, low, high, and very high. Scores (1) Very High $=81.25-100$, (2) High $=62.49-81.24$, (3) Low $=43.73-62.48$, and (4) $24.97-43.72=$ Very Low.

This study's data analysis tool uses the Partial Least Square (PLS). PLS was developed to test weak theory and weak data, such as a small sample size of fewer than 100 data or data normality problems (Gozahali and Latan, 2015). PLS is a componentbased approach for testing structural equation models. PLS is a predictive model that can explain the presence or absence of a relationship between variables and can simultaneously analyze the constructs formed.

\section{Results and Discussion}

The push motivation variable consists of six indicators: Escape from a perceived mundane environment, Exploration and evaluation of self, Relaxation, Prestige, 
Enhancement of kinship relationship, and Facilitation of social interaction. Each of these indicators consists of several statements, which are then filled in. by the respondent to know the description of the respondent's motivation. The report can be seen in the following table:

Table 1. Push Motivation of Jabodetabek Tourists

\begin{tabular}{|c|c|c|c|c|c|c|c|c|c|c|}
\hline \multicolumn{11}{|c|}{ Escape from a perceived mundane environment } \\
\hline \multirow{2}{*}{ Statement } & \multicolumn{4}{|c|}{ Scale } & \multirow{2}{*}{ Score } & \multirow{2}{*}{$\begin{array}{l}\text { Ideal } \\
\text { Score }\end{array}$} & \multirow{2}{*}{$\%$} & \multirow{2}{*}{ Category } & \multirow{2}{*}{$\begin{array}{c}\text { Average } \\
(\%)\end{array}$} & \multirow{2}{*}{ Category } \\
\hline & 1 & 2 & 3 & 4 & & & & & & \\
\hline 1 & 0 & 5 & 16 & 79 & 374 & 400 & 93.50 & Very good & \multirow{3}{*}{93.25} & \multirow{3}{*}{ Very good } \\
\hline 2 & 0 & 2 & 16 & 82 & 380 & 400 & 95.00 & Very good & & \\
\hline 3 & 1 & 7 & 18 & 74 & 365 & 400 & 91.25 & Very good & & \\
\hline \multicolumn{11}{|c|}{ Exploration and evaluation of self } \\
\hline \multirow{2}{*}{ Statement } & \multicolumn{4}{|c|}{ Scale } & \multirow{2}{*}{ Score } & \multirow{2}{*}{$\begin{array}{l}\text { Ideal } \\
\text { Score }\end{array}$} & \multirow{2}{*}{$\%$} & \multirow{2}{*}{ Category } & \multirow{2}{*}{$\begin{array}{c}\text { Average } \\
(\%)\end{array}$} & \multirow{2}{*}{ Category } \\
\hline & 1 & 2 & 3 & 4 & & & & & & \\
\hline 4 & 7 & 16 & 10 & 67 & 337 & 400 & 84.25 & Very good & \multirow{3}{*}{86.67} & \multirow{3}{*}{ Very good } \\
\hline 5 & 1 & 12 & 18 & 69 & 355 & 400 & 88.75 & Very good & & \\
\hline 6 & 3 & 14 & 15 & 68 & 348 & 400 & 87.00 & Very good & & \\
\hline \multicolumn{11}{|c|}{ Relaxation } \\
\hline \multirow{2}{*}{ Statement } & \multicolumn{4}{|c|}{ Scale } & Scoro & Ideal & $\%$ & Cateogry & Average & Cateogry \\
\hline & 1 & 2 & 3 & 4 & Score & Score & $\%$ & Category & & Category \\
\hline 7 & 3 & 5 & 21 & 71 & 360 & 400 & 90.00 & Very good & & \\
\hline 8 & 1 & 3 & 23 & 73 & 368 & 400 & 92.00 & Very good & 91.00 & Very good \\
\hline 9 & 1 & 4 & 25 & 70 & 364 & 400 & 91.00 & Very good & & \\
\hline & & & & & & Prestige & & & & \\
\hline Statement & & & ale & & Scoro & Ideal & $\%$ & Cateogry & Average & Cateogry \\
\hline Statement & 1 & 2 & 3 & 4 & score & Score & $\%$ & Category & & Category \\
\hline 10 & 21 & 16 & 19 & 44 & 286 & 400 & 71.50 & Good & & \\
\hline 11 & 16 & 18 & 19 & 47 & 297 & 400 & 74.25 & Good & 72.50 & Good \\
\hline 12 & 19 & 20 & 16 & 45 & 287 & 400 & 71.75 & Good & & \\
\hline & & & & Enl & ncement & of kinsh & ip relat & onship & & \\
\hline Statement & & & ale & & Scoro & Ideal & 0 & Coteory & Average & Caterory \\
\hline statement & 1 & 2 & 3 & 4 & score & Score & $\%$ & Category & $(\%)$ & Category \\
\hline 13 & 15 & 23 & 13 & 49 & 296 & 400 & 74.00 & Good & & \\
\hline 14 & 9 & 15 & 17 & 59 & 326 & 400 & 81.50 & Very good & 77.42 & Good \\
\hline 15 & 14 & 15 & 21 & 50 & 307 & 400 & 76.75 & Good & & \\
\hline & & & & & cilitation & of socia & intera & tion & & \\
\hline Statement & & & ale & & Score & Ideal & $\%$ & Cateoory & Average & Cateoory \\
\hline statement & 1 & 2 & 3 & 4 & & Score & & Category & $(\%)$ & Category \\
\hline 16 & 20 & 16 & 24 & 40 & 284 & 400 & 71.00 & Good & & \\
\hline 17 & 17 & 15 & 27 & 41 & 292 & 400 & 73.00 & Good & 77.25 & Good \\
\hline 18 & 5 & 8 & 18 & 69 & 351 & 400 & 87.75 & Very good & & \\
\hline & & & & Ave & age (\%) & & ategor: & Total Perc & ption Var & ables \\
\hline $\mathbf{P e}$ & 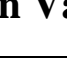 & Ia & & & 3.01 & & & Very g & & \\
\hline
\end{tabular}


Based on the accumulated answers from the results of the questionnaires that the respondents have filled out in table 1, it can be seen that the average value of escape from a perceived mundane environment is $93.25 \%$ or is in the very good category. The high score on this indicator shows that respondents in Greater Jakarta have boredom from their daily environment, which is starting to feel routine and boring. The average Relaxation value is $91 \%$ or is in the very good category. The high score on this indicator shows that respondents who live in Jabodetabek have the motivation to take a vacation because they want to get the opportunity to evaluate and find something more about themselves (explore). The average value of Exploration and evaluation of self is $86.67 \%$ or is in the very good category. The high score on the relaxation variable proves that the respondents want to relax their mental state or relax their physical state in Bandung City. The average Prestige value is $72.5 \%$ or is in the good category even though it does not reach a very high score, it still reflects that respondents who visit the city of Bandung are motivated to travel because they consider tourism to Bandung a symbol of an upscale lifestyle. The average value of enhancing kinship relationship is $77.42 \%$ or is in a good category. It shows that the respondent's motivation is to improve family relations, which is included in the high category. The average Facilitation of social interaction is 77, $25 \%$ or is in the good category. It shows that the respondents have a motivation for tourism because tourism is considered a means that provides the opportunity to meet new people in the city of Bandung.

The pull motivation variable consists of six indicators: Novelty, Static factor, Dynamic Factor, Current Decision, Commercial, and Information/advertisement destination. Each of these indicators consists of several statements that the respondent then fills in to know the description of the attractor motivation of the respondent. The report can be seen in the following table:

Table 2. Pull Motivation of Jabodetabek Tourists

\begin{tabular}{|c|c|c|c|c|c|c|c|c|c|c|}
\hline \multicolumn{11}{|c|}{ Novelty } \\
\hline \multirow{2}{*}{ Statement } & \multicolumn{4}{|c|}{ Scale } & \multirow{2}{*}{ Score } & \multirow{2}{*}{$\begin{array}{l}\text { Ideal } \\
\text { Score }\end{array}$} & \multirow{2}{*}{$\%$} & \multirow{2}{*}{ Category } & \multirow{2}{*}{$\begin{array}{c}\text { Average } \\
(\%)\end{array}$} & \multirow{2}{*}{ Category } \\
\hline & 1 & 2 & 3 & 4 & & & & & & \\
\hline 1 & 3 & 5 & 24 & 68 & 357 & 400 & 89.25 & Very good & \multirow{3}{*}{90.42} & \multirow{3}{*}{ Very good } \\
\hline 2 & 3 & 6 & 18 & 73 & 361 & 400 & 90.25 & Very good & & \\
\hline 3 & 0 & 4 & 25 & 71 & 367 & 400 & 91.75 & Very good & & \\
\hline \multicolumn{11}{|c|}{ Static Factor } \\
\hline \multirow{2}{*}{ Statement } & \multicolumn{4}{|c|}{ Scale } & \multirow{2}{*}{ Score } & \multirow{2}{*}{$\begin{array}{l}\text { Ideal } \\
\text { Score }\end{array}$} & \multirow{2}{*}{$\%$} & \multirow{2}{*}{ Category } & \multirow{2}{*}{$\begin{array}{c}\text { Average } \\
(\%)\end{array}$} & \multirow{2}{*}{ Category } \\
\hline & 1 & 2 & 3 & 4 & & & & & & \\
\hline 4 & 1 & 5 & 16 & 78 & 371 & 400 & 92.75 & Very good & \multirow{3}{*}{93.83} & \multirow{3}{*}{ Very good } \\
\hline 5 & 0 & 3 & 15 & 82 & 379 & 400 & 94.75 & Very good & & \\
\hline 6 & 0 & 4 & 16 & 80 & 376 & 400 & 94.00 & Very good & & \\
\hline \multicolumn{11}{|c|}{ Dynamic Factor } \\
\hline \multirow{2}{*}{ Statement } & \multicolumn{4}{|c|}{ Scale } & \multirow{2}{*}{ Score } & \multirow{2}{*}{$\begin{array}{l}\text { Ideal } \\
\text { Score }\end{array}$} & \multirow{2}{*}{$\%$} & \multirow{2}{*}{ Category } & \multirow{2}{*}{$\begin{array}{c}\text { Average } \\
(\%)\end{array}$} & \multirow{2}{*}{ Category } \\
\hline & 1 & 2 & 3 & 4 & & & & & & \\
\hline 7 & 1 & 3 & 19 & 77 & 372 & 400 & 93.00 & Very good & \multirow{2}{*}{94.25} & \multirow{2}{*}{ Very good } \\
\hline 8 & 1 & 1 & 13 & 85 & 382 & 400 & 95.50 & Very good & & \\
\hline \multicolumn{11}{|c|}{ Current Decision } \\
\hline Statement & & & ale & & Scoro & Ideal & $\%$ & Cateogry & Average & eqary \\
\hline Statement & 1 & 2 & 3 & 4 & score & Score & $\%$ & Category & $(\%)$ & Category \\
\hline
\end{tabular}




\begin{tabular}{|c|c|c|c|c|c|c|c|c|c|c|}
\hline 9 & 2 & 10 & 22 & 66 & 352 & 400 & 88.00 & Very good & \multirow{3}{*}{88.50} & \multirow{3}{*}{ Very good } \\
\hline 10 & 1 & 6 & 29 & 64 & 356 & 400 & 89.00 & Very good & & \\
\hline 11 & 0 & 7 & 17 & 76 & 369 & 400 & 92.25 & Very good & & \\
\hline \multicolumn{11}{|c|}{ Commercial } \\
\hline \multirow{2}{*}{ Statement } & \multicolumn{4}{|c|}{ Scale } & \multirow{2}{*}{ Score } & \multirow{2}{*}{$\begin{array}{l}\text { Ideal } \\
\text { Score }\end{array}$} & \multirow{2}{*}{$\%$} & \multirow{2}{*}{ Category } & \multirow{2}{*}{$\begin{array}{c}\text { Average } \\
(\%)\end{array}$} & \multirow{2}{*}{ Category } \\
\hline & 1 & 2 & 3 & 4 & & & & & & \\
\hline 12 & 2 & 8 & 21 & 69 & 357 & 400 & 89.25 & Very good & \multirow{3}{*}{88.25} & \multirow{3}{*}{ Very good } \\
\hline 13 & 1 & 12 & 24 & 63 & 349 & 400 & 87.25 & Very good & & \\
\hline 14 & 3 & 8 & 26 & 63 & 349 & 400 & 87.25 & Very good & & \\
\hline \multicolumn{11}{|c|}{ Information } \\
\hline \multirow{2}{*}{ Statement } & \multicolumn{4}{|c|}{ Scale } & \multirow{2}{*}{ Score } & \multirow{2}{*}{$\begin{array}{l}\text { Ideal } \\
\text { Score }\end{array}$} & \multirow{2}{*}{$\%$} & \multirow{2}{*}{ Category } & \multirow{2}{*}{$\begin{array}{c}\text { Average } \\
(\%)\end{array}$} & \multirow{2}{*}{ Category } \\
\hline & 1 & 2 & 3 & 4 & & & & & & \\
\hline 15 & 6 & 10 & 22 & 62 & 340 & 400 & 85.00 & Very good & \multirow{3}{*}{88.13} & \multirow{3}{*}{ Very good } \\
\hline 16 & 0 & 8 & 19 & 73 & 365 & 400 & 91.25 & Very good & & \\
\hline 17 & 12 & 12 & 19 & 57 & 321 & 400 & 80.25 & Good & & \\
\hline \multirow{2}{*}{\multicolumn{4}{|c|}{ Perception Variable }} & \multicolumn{2}{|c|}{ Average (\%) } & \multicolumn{5}{|c|}{ Category Total Perception Variables } \\
\hline & & & & \multicolumn{2}{|c|}{90.56} & \multicolumn{5}{|c|}{ Very good } \\
\hline
\end{tabular}

Based on the accumulated answers from the results of the questionnaires that respondents have filled out in table 2, it can be seen that the average Novelty value is 90.42 $\%$ or is in the very good category. The high novelty score indicates that the respondents traveled to Bandung because of curiosity, adventure, new and different. The average value of the Static factor is $93,83 \%$ or is in the very good category. The high static factor score indicates that the respondents traveled to Bandung because of interesting natural factors such as beautiful and relaxed nature. The average dynamic factor value is $94.25 \%$ or is in the very good category. The high score on the dynamic factor indicator shows that the respondents are motivated to visit Bandung because of tourist attractions, entertainment, etc., that are the main attraction. The average current decision value is 88.5 $\%$ or is in the very good category. The high score on the current decision indicator shows that respondents are interested in traveling to Bandung because the goods and services sold in Bandung are more affordable. The average commercial value is $88.25 \%$ or is in the very good category. The high score on the commercial indicator shows that respondents are interested in traveling to Bandung because many handicrafts make it enjoyable to visit. The average value of Information/Advertisement Destination is $88.13 \%$ or is in the very good category. The high score on indicator 2. Information/Advertisement Destination shows that respondents are interested in traveling to Bandung because there is a lot of information. Hence, they make tourism to Bandung a recommendation for tourist attractions.

Loyalty variable consists of four indicators: Repeat Purchases, purchase across product and service line, refers other, demonstrates an immunity to the full of competition in which each of these indicators consists of several statements which the respondent then fills in to find out the description of the respondent's attracting motivation. This description can be seen in the following table: 
Table 3. Jabodetabek Tourist Loyalty

\begin{tabular}{|c|c|c|c|c|c|c|c|c|c|c|}
\hline \multicolumn{11}{|c|}{ Tourist Visitor Loyalty } \\
\hline \multirow{2}{*}{ Statement } & \multicolumn{4}{|c|}{ Scale } & \multirow{2}{*}{ Score } & \multirow{2}{*}{$\begin{array}{l}\text { Ideal } \\
\text { Score }\end{array}$} & \multirow{2}{*}{$\%$} & \multirow{2}{*}{ Category } & \multirow{2}{*}{$\begin{array}{c}\text { Average } \\
(\%)\end{array}$} & \multirow{2}{*}{ Category } \\
\hline & 1 & 2 & 3 & 4 & & & & & & \\
\hline 1 & 0 & 1 & 12 & 87 & 386 & 400 & 96.50 & Very good & \multirow{4}{*}{94.25} & \multirow{4}{*}{ Very good } \\
\hline 2 & 1 & 6 & 17 & 76 & 368 & 400 & 92.00 & Very good & & \\
\hline 3 & 1 & 5 & 18 & 76 & 369 & 400 & 92.25 & Very good & & \\
\hline 4 & 1 & 4 & 16 & 79 & 373 & 400 & 93.25 & Very good & & \\
\hline \multirow{2}{*}{\multicolumn{4}{|c|}{ Perception Variable }} & & $\begin{array}{l}\text { erage } \\
\% \text { ) }\end{array}$ & \multicolumn{5}{|c|}{ Category Total Perception Variables } \\
\hline & & & & \multicolumn{2}{|c|}{94.25} & \multicolumn{5}{|c|}{ Very good } \\
\hline
\end{tabular}

Based on the accumulated answers from the results of the questionnaires that respondents have filled out in table 3, it can be seen that the score on the Repeat Purchases indicator listed in the first statement is $96.5 \%$ or is in the very good category. The high score of repeat purchases shows that respondents like to revisit Bandung. The Purchase across Product and Service Line indicator score stated in the first statement is $92 \%$ or is in the very good category. The high score of Purchase across Product and Service Line stated in the second statement shows that respondents want to travel to Bandung and enjoy culinary delights in Bandung. The Refers other indicator listed in the first statement is $92.25 \%$ or is in the very good category. The high score of Refers other stated in the third statement indicates that respondents will recommend Bandung as a tourist destination to their friends or family. The Demonstrates an Immunity to The Full of Competition indicator stated in the first statement is $93.25 \%$ or is in the very good category. The high score of Demonstrates an Immunity to The Full of Competition noted in the fourth statement shows that respondents are not interested in going to other cities for tours, they want to go to Bandung City.

Test the validity and reliability in this study seen from the measurement model (outer model). The validity test is seen from the score where all convergent validity values meet the requirements, namely $>0.7$; The discriminant validity value on all indicators meets the requirements, namely all cross-loading values > other indicators, then all AVE scores > 0.5 . This proves that the indicators and statement items in the research are valid and can be tested. In the reliability test, the indicator is reliable if the composite reliability value and Cronbach's alpha have a value $>0.7$. In this study, both values have a value above 0.7 which means the indicators are said to be reliable.

Hypothesis testing in this study uses Partial Least Square (PLS), where the advantage of this PLS is that it does not require assumptions and can be estimated with a relatively small number of samples. The tool used is the SmartPLS 3.0 application specifically designed to estimate structural equations based on variance. Hypothesis testing can be seen from the path coefficients generated from the bootstrapping process. To determine path coefficient values between variables in the structural model and the significance of the hypotheses in this study. (1) If the value of t count ( $t$ statistic) < value t table then $\mathrm{H} 0$ is accepted, $\mathrm{H} 1$ is rejected and (2) If the value of $\mathrm{t}$ count ( $\mathrm{t}$ statistic) $>$ the value of $\mathrm{t}$ table then $\mathrm{H} 0$ is rejected, $\mathrm{H} 1$ is accepted. The T table's value can be known based on a 95\% confidence level and a maximum error of 5\%. The number of samples (n) is 100, and the number of variables $(\mathrm{k})$ is 3 . Based on this, the $\mathrm{T}$ table used in this study is ( $\mathrm{Pr}=0.05$ (two directions); $\mathrm{df}=97$ ) which is 1.98 . The following is a picture of bootstrapping results in this study: Figure 1. Bootstrapping - Full Research Model 


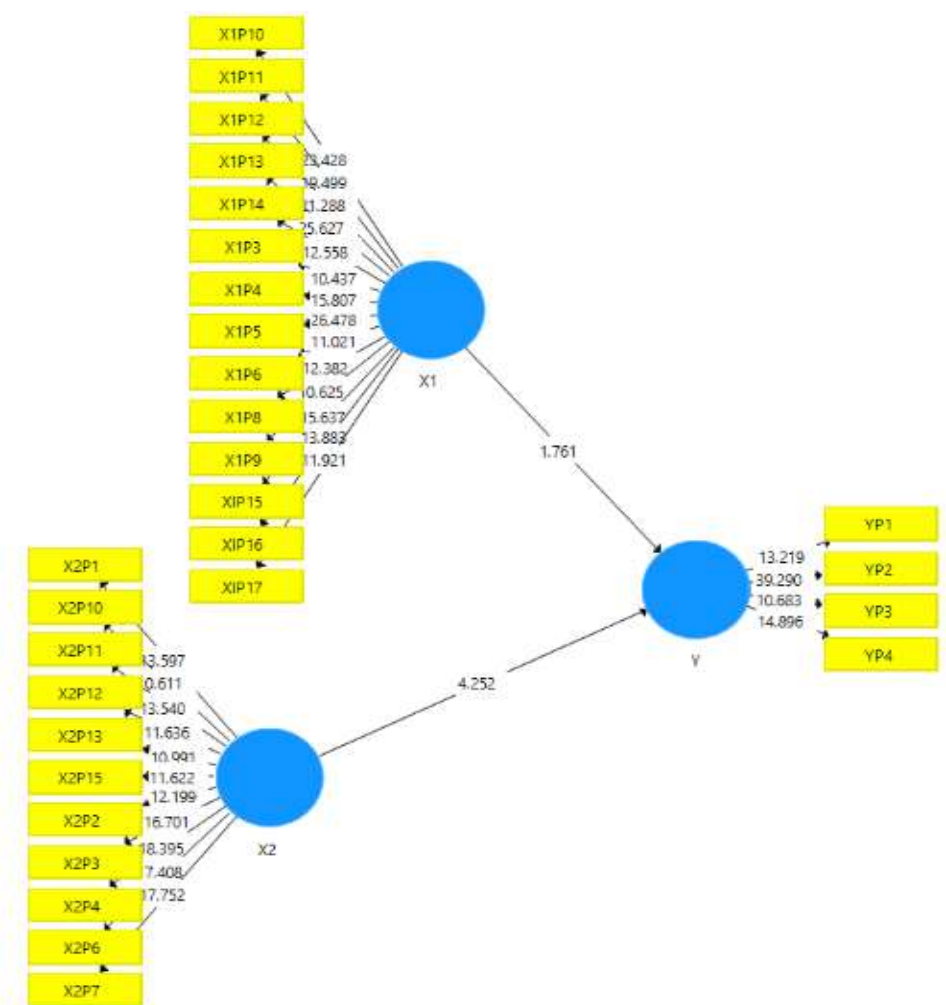

Figure 1. Bootstrapping

Based on Figure 1, the t-statistical values for each indicator variable have a atstatistical value more significant than the t-table, which is 1.98 . It shows that each indicator has a significant level of prediction on its variables. Hypothesis testing can also be seen in the following path coefficients table:

Table 4. Data Processing Results

\begin{tabular}{|l|l|l|l|l|l|}
\hline & $\begin{array}{c}\text { Original } \\
\text { Sample } \\
(\boldsymbol{O})\end{array}$ & $\begin{array}{c}\text { Sample } \\
\text { Mean } \\
(\boldsymbol{M})\end{array}$ & $\begin{array}{c}\text { Standard } \\
\text { Deviation } \\
(\text { STDEV })\end{array}$ & $\begin{array}{c}\text { T Statistics } \\
(\text { O/STDEV })\end{array}$ & $\begin{array}{c}\boldsymbol{P} \\
\text { Values }\end{array}$ \\
\hline $\begin{array}{l}\text { Loyalty Encouraging } \\
\text { Motivation } \rightarrow \text { ( }\end{array}$ & 0.236 & 0.233 & 0.134 & 1,761 & 0.079 \\
\hline $\begin{array}{l}\text { Loyalty Attractor } \\
\text { Motivation } \rightarrow\end{array}$ & 0.588 & 0.600 & 0.138 & 4.252 & 0.000 \\
\hline
\end{tabular}

Based on Table 1 above, the t statistic of 1.761 is smaller than the table of 1.98 , meaning that the driving motivation does not affect the loyalty of Jabodetabek tourists. While the t statistic (4.252) is greater than the t table of 1.98, meaning that there is an influence between Attractive Motivation on Loyalty. The magnitude of the effect can be seen from the original sample, which is 0.588 , which means moderate because it is less than 0.75 and more than 0.50. It means that the higher the towing motivation of Jabodetabek tourists, the higher their loyalty will be.

The determinant factors in the Pull Motivation and Push Motivation variables are seen from the average scores in the table below: 
Table 5. Determinant Factors of Motivation

\begin{tabular}{|l|l|c|}
\hline \multicolumn{1}{|c|}{ Variable } & \multicolumn{1}{|c|}{ Indicator } & Score (\%) \\
\hline \multirow{4}{*}{$\begin{array}{l}\text { Driving Motivation } \\
\text { ( Push Motivation })\end{array}$} & Escape from a perceived mundane environment & 93.25 \\
\cline { 2 - 3 } & Exploration and evaluation of self & 86.67 \\
\cline { 2 - 3 } & Relaxation & 91.00 \\
\cline { 2 - 3 } & Prestige & 72.50 \\
\cline { 2 - 3 } & Enhancement of kinship relationship & 77.42 \\
\cline { 2 - 3 } ( Pacilitation of social interaction & 77.25 \\
\hline & Novelty & 90.42 \\
\cline { 2 - 3 } & Static Factor & 93.83 \\
\cline { 2 - 3 } & Dynamic Factor & 94.25 \\
\cline { 2 - 3 } & Current Decision & 88.50 \\
\cline { 2 - 3 } & Commercial__ & 88.25 \\
\cline { 2 - 3 } & Information & 88.13 \\
\hline
\end{tabular}

Push Motivation variable, there are two highest scores of the six indicators. These indicators are Escape from a perceived mundane environment with a score of $93.25 \%$ and Relaxation $91.00 \%$, meaning that Jabodetabek tourists visit Bandung because they feel bored and bored with the routine in their domicile city, so they decide to travel to Bandung. In addition, Jabodetabek tourists visit Bandung because they want to relax, which is related to conditions in Bandung which can be relaxing compared to the Jabodetabek area. Besides Push Motivation, there is a Pull Motivation variable, in which there is also an indicator that has the highest score. The highest score is $94.35 \%$ on the Dynamic Factor indicator and Static Factor, 93.83\%. It means that tourists choose Bandung to be a tourist spot because there are exciting places that visited, besides the climate and atmosphere in Bandung is also a factor that causes Jabodetabek tourists to be interested in going on a trip Bandung. Based on the average score on the Push Motivation and Pull Motivation variables, it can be concluded that there are determinant factors that become a priority in motivating Jabodetabek tourists so that it can say that $\mathrm{H} 0$ is rejected and $\mathrm{H} 3$ is accepted.

\section{Conclusion}

Based on the research and discussion on the Analysis of Determinants of Loyalty Factors for Bandung Tourists, it can be concluded that (1) Jabodetabek tourists have high motivation, both push motivation and pull motivation, and also high loyalty to the city of Bandung. It means that Jabodetabek tourists are interested in visiting Bandung and tend to return to Bandung. (2) Push Motivation does not affect the loyalty of Jabodetabek tourists. Although the results show that the driving motivation does not significantly influence the loyalty of Jabodetabek tourists, we can know that in the driving motivation, the strongest determinants are Escape from a perceived mundane environment and Relaxation. (3) Pull motivation affects the loyalty of Jabodetabek tourists. For tourists, the determinant factors of towing motivation are the Dyanamic Factor and the Static Factor.

This research is expected to be a reference for related parties, especially for researchers in related fields and tourism managers in the city of Bandung. This research can illustrate that it turns out that Jabodetabek tourists have an attachment to visiting Bandung. Therefore, tourism area holders and entrepreneurs in Bandung are expected to use this opportunity to maximize their potential in their respective fields further. 


\section{References}

Aaker, David A and George S. Day. (2012). Marketing Research (11 Th edition). Aptara Corporation. United States of America.

Awaritefe, OD. (2004). Motivation and other considerations in tourist destination choice: a case study of Nigeria. Tourism Geogr. 6(3): 303 - 330.

Crompton, JL (1979). Motivations for Pleasure Vacations, Annals of Tourism Research, 6(4), 408-424

Dianti, Olivia. (2014). Pushing and Pulling Factors of Surabaya Tourists Traveling to Penang, Malaysia.

Griffin, Jill. (2008). Customer Loyalty How To Earn It, How To Keep It. Kentucky: McGraw Hill.

Hasibuan, Malay SP. (2008). Human Resource Management. Jakarta: Earth Literacy Publisher.

Hassan, Iqbal. (2004). Research Data Analysis with Statistics. Earth Literature. Jakarta.

Juliansyah Noor. (2011). Research Methodology. Jakarta: Kencana.

Kotler, Philip \& Kevin L. Keller. (2012). Marketing Management (14th edition). Upper Saddle River. New Jersey: Pearson Prentice Hall.

Lovelock, Christopher \& Jochen Wirtz. (2019). Service Marketing. New Jersey: Pearson Prentice Hall.

Mohammad, Bashar Aref and Al-Haj Mohammad. (2010). an Analysis of Push and Pull Travel Motivations of Foreign Tourists to Jordan.

Oliver, Richard L. (1999), "Whence, Consumer Loyalty?” Journal of Marketing, Vol. 63, 33-34.

Philip, Kotler. (2000). Marketing Management: Millennium Edition (10th edition), International Edition. New Jersey: Prentice Hall.

Shah, M. et al. (2020). The Development Impact of PT. Medco E \& P Malaka on Economic Aspects in East Aceh Regency. Budapest International Research and Critics Institute-Journal (BIRCI-Journal). P. 276-286.

Sugiyono. (2007). Business Research Methods. Bandung: Alphabeta

Sumarwan. (2008). Consumer behavior. Jakarta: GI Publisher

Yannizar, et al. (2020). Analysis of Good Corporate Governance, Free Cash Flow, Leverage towards Earning Management, and Shareholder Wealth in Service Sector Companies Listed on the Indonesia Stock Exchange. Budapest International Research and Critics Institute-Journal (BIRCI-Journal).P. 2567j-2567v.

Zikumnd, William. (2003). Business Research Methods. (3 Th edition). SOUTHWESTERN. United States of America. 